\title{
Preparing Pre-service Primary Teachers to Teach with Technology: A Case of England
}

\author{
Dr. İpek SARALAR-ARAS, The University of Nottingham, The United Kingdom, saralar.ipek@gmail.com \\ ORCID: 0000-0002-4942-4408
}

Kübra Firat, The University of Nottingham, The United Kingdom,kbr.firat@gmail.com

ORCID: 0000-0002-1981-7542

\begin{abstract}
The purpose of this study is to investigate pre-service primary teachers' perspectives on their technology training sessions throughout the teacher training year and its effects on shaping their future lessons. This one-year training degree in England is called as the Postgraduate Certificate in Education or the PGCE in short. Pre-service teachers are asked to attend up to 60 credits at the master's level in order to complete the requirements of the degree. The participants of the current study were six pre-service primary teachers attending the PGCE course at a university in England. The data were collected through semi-structured interviews. All of the participants took part in forty-five minutes to hour-long one-to-one interviews in one of the classes at the university. Thematic analysis was conducted to analyze the data. The findings indicated that pre-service teachers were willing to integrate technology into their future lessons although they do not feel confident about the applications of different teaching approaches when they use technology. They mostly considered technology as a hook at the beginning of the lessons, listed various technological sources and explained how they plan to integrate these into their future lessons.
\end{abstract}

Keywords: Pre-service primary teachers, PGCE course, technology-integration, mathematics, literacy

$\begin{array}{lll}\text { Received: 03.11.2020 Accepted: 10.12.2020 Published: 09.01.2021 } & \text { Ac2 }\end{array}$

\section{INTRODUCTION}

With the rapid advancement of technology and its devices, students have the opportunity to make use of technology in their learning more than ever. Yet, there need to be knowledgeable and skilled teachers who can introduce and teach children how to use technology in their learning processes. Teachers mainly become the decision-makers of the way technological tools are used in their lessons or, even, choosing not to integrate any technological tools in their lessons (Ertmer, 2005). Especially, teachers in primary school can have a more crucial role in using these tools than teachers at a higher level of schooling since primary school students are more dependent on learning from the school.

To have a stimulating learning environment equipped with technological devices, primary school teachers should have a sufficient amount of expertise and knowledge in using it. Teacher preparation years is the duration that candidate teachers should learn and apply different usage of technological tools in their teaching to gain proficiency and trust in themselves (Hodgkinson \& Wild, 1994).

The majority of the reviewed studies has been focused on experiences after the teacher education rather than throughout the course or by the end of teacher education (e.g., Hannam, Stephenson, \& Smyth, 1976; Marable \& Raimondi, 2007; Newby, 1991). There is a scarcity of research on the candidate teachers' perspectives of technology integration immediately before they start their jobs (Andrews \& Quinn, 2005; Marable \& Raimondi, 2007). In this study, as a response to the need in this area of research, we aimed to find out the perspectives of pre-service teachers through a case study on the technology training lessons during their teacher training year and its influence on their views regarding technology integration in their lessons after graduation. That would eventually illustrate how the candidate teachers feel ready to integrate technology into their lessons in their first year of the teaching profession and beyond after successful completion of their teacher education year. 


\section{BACKGROUND}

\section{Teachers' Beliefs and Perspectives}

Primary school is the first step for these students to learn many subjects from mathematics and science to history and geography. Thus, meeting the technological needs of students in primary school is always considered as a very important criterion in English primary school curricula (Department for Education [DfE], 2004, 2013b). Primary school teachers can be thought of as the core agency of planning and delivering lessons whose objectives are predetermined by the primary school curriculum. Learning their beliefs and perspectives on technology integration into their lessons, therefore, is one of the most important criteria to understand whether they meet the needs of their students.

Beliefs and perspectives are essential factors in their teaching which shape their perceptions concerning many aspects including their choices of instructional methods and the role of technology integration into their lessons (Mainali \& Key, 2012; Saralar \& Ainsworth, 2017). Teachers are expected to meet the needs of a new generation of students who come with the different demands than their predecessors (Mishra \& Koehler, 2006; Saralar, Isiksal, \& Akyuz, 2016; Schmidt et al., 2009). The new generation of students is started to be called as digital natives which, for us, means people who grow up in a digital age rather than meeting with the technologies like mobile phone or tablet at a later age (Prensky, 2012). Therefore, teachers are increasingly in need of flourishing their students' ability to use technology from the early years of schooling.

Teachers' beliefs and their perspectives are inseparable aspects of their teaching (Shulman, 1986; Wright, Horn, \& Sanders, 1997). The existing literature (Andrews \& Quinn, 2005; Marable \& Raimondi, 2007) illustrate that the initial year of the teaching was hard for the primary teachers. They reported a number of challenges including dissatisfaction from previous training and school principals, lack of manipulatives and digital technologies they previously intended to use (Marable \& Raimondi, 2007), as well as difficulties in getting students' attention, emphasizing the relevance of the learning objectives with the real life, building confidence in teaching, and imposing rewards and punishments (Newby, 1991). Moreover, some of these emphasized difficulties of adopting a new ICT-based curriculum for primary education with limited guidance (Domingo \& Garganté, 2016; Vanderlinde \& Braak, 2011). Therefore, the perspectives of the in-service teachers could be influenced by the factors that are external to themselves such as, the available technological tools and corporation between the teaching staff (Roussinos and Jimoyiannis, 2019). Overall, the research studies evidently indicate that the teachers' perspectives and beliefs are interlinked with their experiences, which could change depending on the external factors as Roussinos and Jimoyiannis (2019) and the previously mentioned studies identified. Thus, doing research with pre-service teachers just before starting their first year of teaching is important since their perspectives and beliefs would not be related to or influenced by the external factors.

\section{Technology Integration into English Curriculum and Teacher Training Courses}

The need for the integration of technology in the schools of primary children gained speed since the establishment of the first national curriculum in Wales and England in 1988 because the statutory curriculum required primary school students between five to sixteen years of age to have the ability to use technological tools (Hodgkinson \& Wild, 1994). Therefore, the researchers in the year of 1994 believed that to teach technology to those students, candidate teachers should prepare themselves for teaching students how to use technology in their lives and the Postgraduate Certificate in Education (PGCE) programmes have a critical role in preparing the pre-service teachers to involve technology in their lessons (Hodgkinson \& Wild, 1994).

From 1988 to 2019, the desire of the English government for technology integration in primary school has increased in that not only in primary school but also in the early years' education they have set more specific and clear expectations regarding technology integration. Under the subject design and technology, they planned four aims that students can have at the end of Key Stage 2 and two of them are directly related to the students' technology-use. They expect primary school children to:

1) "develop the creative, technical and practical expertise needed to perform everyday tasks confidently and to participate successfully in an increasingly technological world"

2) "build and apply a repertoire of knowledge, understanding and skills in order to design and make high-quality prototypes and products for a wide range of users" (Department for Education [DfE], 2013a).

In addition to these, the expectations specific to technology use went down to the early years' framework, which is compulsory for all registered schools teaching children from zero to five. The expectation at the end of the foundation stage is: "Children recognise that a range of technology is used in places such as homes and schools. They select and use technology for particular purposes." (Department 
for Education [DfE], 2013c). We need teachers who are capable and confident enough to use technology in their lessons to achieve these goals in order to enable children to achieve the objective.

Also, considering that the PGCE course only lasts one year and people who have bachelor's degrees from very different subjects can apply for it to be primary school teachers, the PGCE course seems to take a more significant role. Pre-service teachers attending to the PGCE constitute the next year's primary school teachers. Current PGCE programmes in many universities are in the progress of developing to meet pre-service teachers' and their students' needs (Sullivan, 2018). Therefore, it is important to look at training sessions on technology integration through the eyes of current PGCE students and their experiences as their current views will potentially give insights into their attitudes toward using technology after being a qualified teacher.

In light of this, the research questions of this study are:

1) What are the perspectives of pre-service teachers on technology training throughout the PGCE year?

2) How do the pre-service teachers benefit from the PGCE course with regard to technology integration into their future lessons?

\section{METHODS}

\section{Research Design}

The researchers selected a case study as the design of this study. Yet there are various types of case study designs such as single-case designs, and multiple-case designs (Yin, 2003). In the current study, holistic single-case design constituted the research design since the participants were studying in the same PGCE programme of the same university. Among different universities, the focused university was considered as one of the typical (i.e., representative) universities which fitted our research aims.

\section{The Context and the Participants}

The university locates in England, having students more than 30.000 each year. The education department opens the PGCE Primary course (5-11 age) for applicants coming from the various educational and professional background. The duration of the course is one full academic year beginning from September to the end of June. The course offers four compulsory modules, two of which are related to school placements. The contents of the remaining two modules are described as learning, teaching in primary school under the light of theories in education. There is no specific explanation of the exact topics to be trained and discussed.

The participants of the study were six (four females, two males) pre-service primary school teachers, studying to become trained teachers. All of them completed the first part of their teacher training and registered to the second half of the PGCE course in a public university in England. They were in their final three to four months before starting to their actual teaching jobs as qualified primary school teachers during the data collection period. The reason for choosing this period of time was partly pragmatic as it was to adapt the remaining lessons according to their needs and meet their expectations before their graduation.

The pre-service teachers had an educational background different from each other as it is shown in the first column of Table 1. All participants had a four-month-long placement in different primary school since they started the PGCE Primary course. They had the opportunity of working with and observing students. Similar to diversity in their educational background, their working experience with children varied before starting the PGCE course. The second column of Table 1 indicates how long they worked with children from nursery (age 3) to year 6 (age 11).

Table 1. Participants' characteristics

\begin{tabular}{|l|l|l|}
\hline Participant & Educational Background & Teaching Experience in months \\
\hline 1 & BA (Hons) Childhood Studies & N/A \\
\hline 2 & BA in English and Spanish & N/A \\
\hline 3 & BSc in Mathematical Physics & Twenty-four \\
\hline 4 & BA in English Literature and Language & Six \\
\hline 5 & BA in Early Childhood Studies & Seven and a half \\
\hline
\end{tabular}




\section{Data Generation and Ethical Considerations}

The data collected through semi-structured one-to-one interviews which lasted forty-five minutes to an hour. Each interview was conducted in one of the classrooms in the participants' university which is a place where participants were already familiar with. Table 2 , on the next page, shows sample interview questions about participants' prior (Phase 1) and current (Phase 2) experience with technology and future (Phase 3) plans about technology integration into their lessons.

The study followed the ethical guidelines of the revised British Educational Research Association and met all requirements of the recent General Data Protection Regulation (BERA, 2011; The University of Nottingham, 2018). All of the participants were voluntarily attended to the study and were provided with the information sheets prior to signing the consent forms. They were aware that they have the right to withdraw at any time during the study.

The audio-recordings of the interview data and their transcriptions were stored in passwordsecured computers. The anonymity was ensured through deleting or changing any information that may disclose participants' identity. Participants' names were replaced with pseudonyms in analysis and reported as participant numbers throughout the article.

Table 2. Phases and sample questions under them

\begin{tabular}{|c|c|}
\hline Phases & Sample questions \\
\hline Phase 1 & $\begin{array}{l}\text { 1. Could you talk about your educational background? } \\
\text { 2. Have you taken any courses solely based on technology integration into the classes? } \\
\text { 2.a. If yes, what are their names? Could you briefly describe their contents? } \\
\text { 2.b. If no, how technology is integrated into the teacher training curriculum? (Notes for } \\
\text { the interviewer: You may deepen the conversation by asking questions on dynamic } \\
\text { technology tools, PPT and Prezi presentations in lesson planning, and use Excel in } \\
\text { projects.) } \\
\text { 3. Which PGCE modules have you completed? } \\
\text { 3.a. Did they include any training on the use of technology in your lessons? } \\
\text { 4. Have you had a chance to work with primary school children before? Could you talk } \\
\text { through your experience? What about the use of technology (observing or using)? Which } \\
\text { age group of children did you work with and how long? }\end{array}$ \\
\hline Phases & Sample questions \\
\hline Phase 2 & $\begin{array}{l}\text { 1. What do you think about the use of technology in primary education? } \\
\text { 1. a. In which phases (start, middle, end) and aspects (while introducing a topic, during } \\
\text { assessment) of your teaching do you think are more effective to integrate technology? } \\
\text { Why? } \\
\text { 2. Have you had a chance to integrate technology into your lessons during school } \\
\text { placements? } \\
\text { 2.a. If so, which technologies did to integrate into your lessons during placement? } \\
\text { 2.b. How do you decide to integrate these technologies? } \\
\text { 2.c. How do the school placements for four days a week affect your decisions on the use } \\
\text { of technology? } \\
\text { 3. How confident are you in teaching with technology? Could you please elaborate more? }\end{array}$ \\
\hline Phase 3 & $\begin{array}{l}\text { 1. How do you plan to integrate technology into your future classes? } \\
\text { 2. Which technologies would you like to integrate into your lessons on } \\
\text { 2.a. number sense and } \\
\text { 2.b. phonics etc.? } \\
\text { 3. Why do you want to integrate such technologies into your future lessons? } \\
\text { 3.a. Why do you think they are effective? } \\
\text { 4. Is there any specific game, software, and/or program you would like to integrate into } \\
\text { your lessons? } \\
\text { 4.a. Why do you prefer to integrate these into your lessons? } \\
\text { 4. What might be the disadvantages of these technologies for you and your students? } \\
\text { Why? }\end{array}$ \\
\hline
\end{tabular}




\section{TPACK Framework and Data Analysis}

The researchers considered the Technology, Pedagogy and Content knowledge framework, in short TPCK or TPACK, as a basis of their data analysis (Mishra \& Koehler, 2006; Niess, 2005, 2006). This framework was an extension of Shulman's (1986) PCK with a further aim to prepare pre-service teachers to teach with technology in addition to the training sessions on pedagogy and content knowledge. Therefore, the analysis of the interview data included the selection of all aspects of technology as well as pedagogy, and content knowledge similar to those of Shin et al. (2009).

It is important to define technology, pedagogy and content for our study before explaining the further analysis step by step. Pedagogical knowledge is 'what is known from how to teach the concept' (Shulman, 1986, p. 6). In our study, it includes pre-service teachers' prior knowledge and discussions on the reasons for choosing particular technological tools, their previous and intended use of these tools in the primary classrooms and decisions on the use of these tools in different phases of the lessons for various purposes from the assessment to the means of student activities to teach particular topics from mathematics and literacy. Content knowledge refers to "the subject matter knowledge of a teacher to be learned or taught" (Koehler \& Mishra, 2009, p. 63). Our study focused on two particular subject matters from mathematics and literacy, which were numeracy in mathematics and phonics in literacy. Finally, in TPACK, educational technology was "about standard technologies, such as books, chalk and blackboard, and more advanced technologies, such as the Internet and digital videos. [Technology knowledge] includes the use of operating systems and computer hardware, and the ability to use standard sets of software tools such as word processors, spreadsheets, browsers, and e-mail" (Mishra \& Koehler, 2006, p. 1027). Educational technology knowledge, in this context, refers to the use of applications, software packages and online tools in the classroom settings in order to support students' learning.

Data analysis started with the transcription of interviews. We transcribed the participants' answers to each interview question separately, i.e., all participants' answers to the first question were written underneath the first question; then, all participants' answers to the second question was written underneath the second question. The same procedure was repeated for all questions.

Thematic analysis was conducted to analyse transcribed data. We read written answers of each interview question repeatedly and coded the aspects of TPACK in the data. Based on the final codes that were emerged in the data, we created themes and put the similar and/or related codes under the same theme as suggested by Miles, Huberman and Saldana (2014). The thematic analysis found three main themes based on the answer we got during the interviews:

(1) Teaching and technology experience as a student: This theme explored pre-service teachers' educational background. It included pre-service teachers' experiences with technology in their bachelor and PGCE degrees. In other words, it included the findings on how they were taught with technology as a student.

(2) Perceived technology competency and its importance: This second theme looked for pre-service teachers' self-confidence and internal experiences with the technology integration into classrooms. This included pre-service teachers' own experiences of teaching with technology during placement or tutoring experiences.

(3) Plans on technology integration: Finally, the third theme discovered pre-service primary school teachers' plans on technology integration in their future lessons. This theme covered plans related to particular technologies in teaching mathematics and literacy. Table 3 shows emerging themes, codes and sub-codes.

Table 3. Themes and codes

\begin{tabular}{|l|l|}
\hline Themes & Codes and sub-codes \\
\hline $\begin{array}{l}\text { Teaching and technology } \\
\text { experience as a learner }\end{array}$ & $\begin{array}{l}\text { Prior knowledge } \\
\text { Observation of teachers and lecturers during PGCE } \\
-\quad \text { Suggestions of teachers and lecturers }\end{array}$ \\
\hline $\begin{array}{l}\text { Perceived technology } \\
\text { competency and practices } \\
\text { with technology }\end{array}$ & $\begin{array}{c}\text { Use of digital tools } \\
-\quad \text { Planning } \\
-\end{array}$ \\
& $\begin{array}{l}\text { Teaching } \\
\text { Confidence } \\
-\quad \text { Knowledge of technological tools - trust }\end{array}$ \\
\hline
\end{tabular}




\begin{tabular}{|c|c|}
\hline $\begin{array}{l}\text { Plans on technology } \\
\text { integration }\end{array}$ & $\begin{array}{l}\text { Use of digital tools } \\
-\quad \text { Mathematics } \\
\text { - } \quad \text { Literacy } \\
\text { Promoting/Hindering student engagement } \\
\text { - } \quad \text { Distractions } \\
-\quad \text { Classroom management } \\
-\quad \text { Students' interest } \\
-\quad \text { Interactive environments }\end{array}$ \\
\hline
\end{tabular}

\section{RESULTS}

The findings of the study showed that there are three main issues discussed by the pre-service teachers. We presented these three themes according to the chronological order. First of all, pre-service teachers' prior technology use together with their PGCE training was discussed in theme 1: teaching and technology experience as a learner, which may have affected their perceptions of technology competency. Following this, their current technology integration practices and competencies were explained in theme 2: perceived technology competency and practices with technology. Finally, theme 3 discussed preservice primary teachers' plans on technology integration and possible examples from their plans.

\section{Teaching and Technology Experience as a Learner}

There was no specific module provided for the participants on technology integration other than a onehour lesson on technology-use until now and there was no expected module by the end. However, they have had opportunities for learning, observing and applying technology into their lessons with the help of their prior knowledge and their observations on teachers and lecturers while using technology in their lessons.

To explain, all the PGCE students had one lecture on technology integration in a class by an invited primary teacher, who was working as an information technology leader in a primary school. Participant 4 explained the content of the lecture as follows:

"It was just like a teacher in a primary school, who like is introducing all new apps and stuff, like how in primary school, they have like iPads for every student and how they do like homework through that apps like Google and stuff how you incorporate that in lessons and like countdown apps like just how you can incorporate the use of an iPad particularly in the classroom."

Participant 5 described other points that were taught in that lesson. She said:

"We learned about how we can use a PowerPoint and apps in our classroom to use assessment for learning and develop children's knowledge."

Considering the description of the participants about the lesson, it seems that the use of technology was introduced across different teaching areas in a very short time.

Other than the session, it is natural that the participants had some knowledge and experience on the use of technology in lessons. They had some knowledge and experience before the PGCE and observations of teachers and lecturers during the year of PGCE. Participants, 34 and 5 stated that they already knew how to use some software and some technological devices. Participant 5 explained how she used her prior knowledge in her teaching as below:

"I just used my prior knowledge of using PowerPoint to create and use a PowerPoint for my lesson. Also, I use my prior knowledge of using the word for lesson planning, creating resources and assessment. However, during the course, we had a session about the use of technology in the classroom. We learned about how we can use a PowerPoint and apps in our classroom to use assessment for learning and develop children's knowledge."

Moreover, participant 3 expressed that she had knowledge of using various technological as follows:

"When it comes to the learning with technology, using computers, smart boards, projectors, tablets, I experienced, you know, this kind of technology was always used."

Lastly, the pre-service teachers had the chance of observing their lecturers while teaching and using technology. All participants said that they observed the lead teacher's use of technology. Similarly, during placements, they observed teachers using technological devices in their lessons. Even though their focus was not teaching how to use technology particularly, while they were using for their own lessons, they suggested advice to the pre-service teachers. Learning by observation enabled them to obtain some knowledge about technology integration into lessons. For example, participant 3 was aware of the 
importance of observing the teachers during placement and emphasised how observation and receiving advice from the lead teachers enabled her to learn more about technology integration. She said:

"I want to put a comma over here because during my first placement I observed a teacher and she was effectively using technology in her lessons. The classroom teacher integrated and thus had a chance to show me many online materials where children can practice their knowledge. I consider placement as a part of my training, so I did not want to skip this."

Similarly, Participant 6 mentioned the lead teacher's use of technology while talking about the observations during the placement and vaguely said:

"I observed the lead teacher's use of technology."

All in all, the PGCE programme did not offer detailed lectures about the use of technology. Yet, the participants had already some technical knowledge and experience. Also, they had the opportunity of observing lecturers and teachers while using technology, which provided an understanding of how to integrate technology in teaching effectively.

\section{Perceived Technology Competency and Practices with Technology}

Perceived technology competency theme, as the second theme, was about pre-service teachers' selfconfidence and experiences with the technology integration into classrooms. This theme covered participants' teaching experiences with technology during tutoring and placement.

Pre-service primary teachers reported that they use educational technologies throughout their lessons from the start to the end but for different purposes in each phase. While planning, they named various tools and ways of integrating them into their lessons. Common tools reported by them found as applications on iPads and tablets (Autodesk SketchBook, ClassDojo, Google Expeditions, Smart Notebook, Showbie and Quick Maths), interactive sketch tools and online games (Cabri, GeoGebra, Geometer's Sketch Pad, Google Classroom, Kahoot and Plickers), office tools (Excel, PowerPoint and Word), and online educational videos (Youtube Kids, Youtube and Khan Academy). More than half of them said they mostly use technologies at the beginning of their lessons when they introduce a topic. For example, Participant 5 said that

"I typically use an application like a hook, you know, as something exciting to engage kids and grab their attention, like google expedition. I think that would be really good to hook a topic. That's all the points really."

All of the participants reported that they found it effective to use online quiz tools at the end of the lessons for assessment. A typical example is Participant 4 who said

"I think it is useful at the end of the lessons when you check for understanding. There is an app where kids have their progress cards. If students answer the assessment question, it reports this to the teacher so you can keep track of the progress of children. I think it would be useful because you can quickly see the results and you can prepare your next lesson accordingly."

It was found that pre-service teachers were unconfident about technology integration when they were asked about their knowledge of technology integration into the lessons. Despite a list of tools they named and used, they were not quite sure about whether they used them effectively in their lessons. Participant 1 reported this with his words by saying

"Honestly, I am not very confident. Children know all these digital stuff more than you do. I, myself, actually am not confident with programs. ... When we are on placement, we go five days a week. But, you do not want to rely on your lesson plan on [an online tool]. Because if it goes wrong, then the whole class ruins."

Similarly, participant 3 said that

"How confident I am in teaching with technology depends on what type of technology but I do not feel confident with sketch programs or software similar. I do think technology is useful though."

Lastly, participant 6 commented on the question regarding how confident she feels about using technology in her classrooms by saying

"Not really [confident]. I feel like I keep giving bad answers but I don't feel confident enough to use any technology in my class. I would rather take some courses on particular technologies I am interested in using, instead of using technology in my class right away."

All of these conclude that participants, currently, believe in the effectiveness of educational technologies in their classrooms. However, they do not feel confident enough to integrate them effectively into their lessons.

\section{Plans on Technology Integration}

Plans on technology integration theme, as the name indicates, explored participants' future plans on technology integration. This theme covered plans related to particular technologies in teaching 
mathematics and literacy. In addition to these, pre-service teachers discussed promoting and hindering students' engagement using technology in the future.

Most of the pre-service primary teachers said that they prefer to integrate digital tools into their lessons on mathematical topics rather than literacy. To illustrate, participant 2 said that

"I regard technology as the tool inside the machine. A computer is not a technology to me, many primary classes have one. All the ready-to-use digital tools are my potential technology to integrate into my lessons. I would integrate these tools such as online games and other ready-to-use digital tools similar to those of Cabri and other sketch tools to teach number sense or basically any topic in mathematics."

He had ideas on how to integrate technology into his mathematics lessons. He continued to explain by giving examples from literacy. He said

"Phonics is a bit different. I am not sure about integrating technology into teaching this. There are many materials such as phonics sets, storybooks, etc., and I would probably use these. ... Many things come with experience. It will be easier for me after having enough classroom experience."

Participant 4 agreed with Participant 2 and added that

"I may integrate things like online learning games, interactive tools, program files and sketch tools into maths lessons, e.g., finding multiples of numbers and touching them on the interactive whiteboard. In literacy, it is like matching the synonyms with each other, and such examples."

All of the participants believe that technology comes with both benefits and disadvantages. They discussed issues related to distractions, classroom management, meeting students' interests and interactive environments. Majority of the pre-service teachers believe that that there will be many distractions when students use a kind of technology. A typical quote from Participant 1 is the following:

"If students do not engage with what they supposed to learn and they focus only on playing with the digital tools, and if I realize that technology does not help students' learning, then it becomes a disadvantage."

Similar to this, Participant 5 said that

"I do not want children to engage with technology too much and disengage with the real world. Children might be distracted from learning objective because they are too busy focussing on the fun element. Technology can sometimes not cooperate and can defeat the whole point of the lesson."

Moreover, half of the pre-service teachers believe that classroom management will be more challenging when they integrate digital tools into their lessons. They had no hesitation to explain their position regarding this. For example, Participant 3 said that

"A disadvantage of using these technologies in the classroom for me could be managing the

classroom. This scares me most nowadays."

Participant 1 supported this idea by saying

"Using some educational technologies in the classroom is so hectic. Children might use them

for the wrong purpose. For example, there are so many inappropriate YouTube videos."

Teachers were not entirely negative on the use of technology. All of them said that they will integrate technologies into their future lessons. There were two main reasons for this decision. First of these is that they all believe that using these technologies increase students' interest in the learning objectives by providing an unusual context. Meanwhile, participants discussed that integration of these technologies meet the needs of the new generation who was born into technology, as technology became a part of their daily life. One of them said that

"I will explain this using the quiz tool I mentioned earlier. (She explained earlier that she plans to upload some photos and videos to ask questions about these on Kahoot.) Kahoot gives all the interesting context that students can discuss with each other. Students will have a chance to engage with the content by actually thinking about it and discussing it in the given time decided by the teacher."

Secondly, they believe that the interactive environments are more likely to be helpful to track students' learning and their feedback related to the lessons. While two of them talked about this in general, the majority of the pre-service primary teachers gave specific examples to the application they may potentially use in their future lessons. A typical example of the generic explanations is the following:

"I believe that these technologies became parts of our lives and that they help to learn. Suppose students are trying to learn a topic and they are struggling, if anyhow a technology facilitates their learning, I would try it. I prefer to focus on advantages such as better learning and increased engagement." 
Another participant supported her by talking about a particular experience from his internship. This one typically presents an example of the majority of the teachers:

"It is engaging to use technology in the lessons. It can improve student engagement in the lesson, enhance their understanding of the concepts. During my last placement, I learned that children enjoyed using technologies in the lesson. They found it fun, interactive and 'bearable', as it gives them a break from writing and enables them to learn and become a researcher."

He also referred to a particular application which he thinks will be useful in his future lessons. The participant anticipated his future positive experiences with some particular tools. For example, he talked about an online interactive tool which uses "Focus on teaching, not technology: This means less time spent struggling with your tech setup, and more time for teaching and learning." as their slogan (Showbie: The Paperless Classroom App for Teachers, 2019). He was aware of the essential tools which this application combines including tools for assignments, feedback and communication.

"Snowbie is an app that enables the teachers and children to access the app anywhere, anytime. It is excellent for formative and summative assessments, setting assignments and introducing new topics. It is less time-consuming, and it enables the teachers to obtain all the children's opinions and feedback."

To sum up, there were two codes for future plans on technology integration: use of digital tools in mathematics and literacy and promoting/hindering student engagement. There were four sub-coded related to the participants' future plans on technology integration: distractions, classroom management, meeting students' interests and interactive environments. While distractions such as focusing on the fun element rather than the learning objective and difficulties of managing the technology-based classroom were mentioned as disadvantages of using technology in the future lessons, meeting students' interest and providing interactive environments were listed as the benefits of it.

\section{DISCUSSION AND CONCLUSION}

\section{Discussion of the Findings}

Technology integration into lessons became almost a must for the primary school teachers since the current curriculum has a set of detailed learning aims on technology. Yet, the findings showed that preservice teachers were not being prepared comprehensively during their PGCE course year. Even though all of them had previous knowledge of different uses of technological devices in their lives, they do not feel confident to integrate technology into their lessons, supporting the findings of Sang and colleagues (2009) with candidate teachers specializing in primary education in China. The low self-confidence of the participants of the current study might be explained through the argument that having different educational and professional backgrounds might have created diversity in the self-confidence of the participants and they did not have a comprehensive pre-service training responding the individual needs of the participants coming from diverse educational and professional backgrounds. We argue that there should be more detailed and comprehensive training sessions being offered to the pre-service teachers during the PGCE year to graduate them at the same or similar levels of confidence. Unfortunately, with the training which did not meet their needs during the PGCE year, these participants are likely to work as teachers with less knowledge and competence in technology than expected by the curriculum, and we may express that they need more training on technology-use as it was found in the study of Czerniak, Lumpe, Haney, and Beck (1999).

The study found out two overarching themes; distractions and classroom management, where the participants explained the disadvantages of using technology in mathematics and literacy lessons. However, they were also aware of its advantages such as increasing students' interest and promoting more interactive learning environments. Most of them mentioned that they would use digital tools in their lessons. However, the study found that the participants prefer to use technological tools in their mathematics lessons rather than literacy lessons. They gave many examples to tools from mathematics but very few examples from the literacy. This finding could be interpreted in two ways; first, it might mean that they did not receive an adequate level of training in their teacher training year about effective technology integration to this particular part of the primary school curriculum. Second, it might be explained through the findings of Starkey (2010) in that the participants' pedagogical content knowledge on literacy is not embedded enough, therefore they did not feel confident to express the possible uses of technology in their literacy lessons plans. As Sullivan (2018) mentioned that the PGCE courses in many universities are still revising and renewing their content. The results showed that the sample PGCE course is one of them that needs improvement in the aspect of teaching the pre-service teachers how to 
effectively integrate technology into their primary lessons in different pedagogical contents such as math and literacy.

\section{Implications and Suggestions for the Future Studies}

The current study found that preservice teachers need extra support for technology integration to lessons. Therefore, it is recommended that the place of technology in the PGCE courses needs to be changed and particularly lessons on technology integration might be increased with the amount of time and richness in its content. Such courses should aim for enhancing pre-service teachers' understanding of how various technological tools could be useful in all lessons and for developing competencies of preservice teachers by both giving theoretical explanations and showing examples from real-life episodes/classrooms. Authors believe that unless theoretical knowledge is supported by practice, learning does not take place fully, so as a second step, preservice teachers should be presented with reallife experience. We are also aware that there are not enough technological devices in every school, hence by creating a primary classroom within the university, students can practice technology, teachers/lecturers can also observe and give feedback to them. By this way, this study suggests that the curriculum of current technology courses in the PGCE courses should be revised and that realistic technology-enhanced exercises for pre-service teachers to practice in actual teaching environments should be applied and incorporated to these courses.

Secondly, the profile of prospective teachers attending PGCE courses changes depending on the year. It would be suggested to assess what the prospective students in a particular year know, how competent they feel, what their thoughts are toward technology use in lessons before starting to plan the module for technology so that the content of the module could better fit the needs and the interests of pre-service teachers. Hence, further research, particularly surveys with a greater number of pre-service teachers, on their needs of educational technology training is needed. Similarly, parallel studies of preservice teachers at lower or higher levels of TPACK may be designed to assess if the teacher candidates' profile and their starting level to the PGCE course contributed to their views on technology integration into lessons. Given that participating PGCE primary students came from various backgrounds, from English Literature to Mathematical Physics, it is important to understand whether their background and starting level to the PGCE course would affect their technology integration competencies is required to be investigated.

Furthermore, the current study provides a detailed investigation of six pre-service teachers' opinions, all attending the PGCE Primary course in a particular university. Different universities may have different approaches in their PGCE course designs hence the prospective teachers from different universities might have different experiences on technology integration. More case studies on technology and its integration to teacher education in other universities, as well as a follow-up study in the same university would be suggested.

Last but not least, this study included the PGCE students, however, it will provide another angle to such research if future studies include the views of the PGCE course leaders and/or lecturers. PGCE course leaders and lecturers are those who set an example to PGCE students, and their technology integration into PGCE courses is important to investigate. Hence, our future research will explore technology integration of the PGCE course leaders and lecturers.

\section{REFERENCES}

Andrews, B. D., \& Quinn, R. J. (2005). The Effects of Mentoring on First-Year Teachers' Perceptions of Support Received. The Clearing House: A Journal of Educational Strategies, Issues and Ideas, 78(3), 110-117. https://doi.org/10.3200/TCHS.78.3.110-117

BERA. (2011). Revised Ethical Guidelines for Educational Research. London: British Educational Research Association.

Czerniak, C. M., Lumpe, A. T., Haney, J. J., \& Beck, J. (1999). Teachers' beliefs about using educational technology in the science classroom. International Journal of Educational Technology, 1(2), 1-18.

Department for Education [DfE]. (2004). The Education: National Curriculum (Key Stage 1 Assessment Arrangements) (England).

Department for Education [DfE]. (2013a). The national curriculum in England: design and technology programmes of study. Retrieved 25 February 2019, from https://www.gov.uk/government/publications/national-curriculum-in-england-design-andtechnology-programmes-of-study/national-curriculum-in-england-design-and-technologyprogrammes-of-study 
Department for Education [DfE]. (2013b). The national curriculum in England: Mathematics programmes of study: key stages 1 and 2 .

Department for Education [DfE]. (2013c). The statutory framework for the early years' foundation stage: Setting the standards for learning, development and care for children from birth to five. Retrieved from https://assets.publishing.service.gov.uk/government/uploads/system/uploads/attachment_data/fi le/596629/EYFS_STATUTORY_FRAMEWORK_2017.pdf

Domingo, M. G., \& Garganté, A. B. (2016). Exploring the use of educational technology in primary education: Teachers' perception of mobile technology learning impacts and applications' use in the classroom. Computers in Human Behavior, 56, 21-28. https://doi.org/10.1016/j.chb.2015.11.023

Ertmer, P. A. (2005). Teacher pedagogical beliefs: The final frontier in our quest for technology integration? Educational Technology Research and Development, 53, 25-39.

http://dx.doi.org/10.1007/BF02504683

Hannam, C., Stephenson, N., \& Smyth, P. (1976). The First Year of Teaching. Penguin Books.

Hodgkinson, K., \& Wild, P. (1994). Tracking the Development of Student Information Technology Capability: IT in a primary postgraduate certificate of education course over three years. Journal of Information Technology for Teacher Education, 3(1), 101-114. https://doi.org/10.1080/0962029940030109

Koehler, M. J., \& Mishra, P. (2009). What is technological pedagogical content knowledge? Contemporary Issues in Technology and Teacher Education, 9(1), 60-70.

Mainali, B. R., \& Key, M. B. (2012). Using dynamic geometry software GeoGebra in developing countries: A case study of impressions of mathematics teachers in Nepal. International Journal for Mathematics Teaching and Learning, 8(1), 1-16.

Marable, M. A., \& Raimondi, S. L. (2007). Teachers' perceptions of what was most (and least) supportive during their first year of teaching. Mentoring \& Tutoring: Partnership in Learning, 15(1), 25-37. https://doi.org/10.1080/13611260601037355

Miles, M. B., A. M. Huberman, \& J. Saldana. (2014). Qualitative Data Analysis: A Methods Sourcebook. 4th ed. USA: Sage.

Mishra, P., \& Koehler, M. J. (2006). Technological pedagogical content knowledge: A framework for teacher knowledge. Teachers College Record, 108(6), 1017-1054.

Newby, T. J. (1991). Classroom motivation: Strategies of first-year teachers. Journal of Educational Psychology, 83(2), 195-200. https://doi.org/10.1037/0022-0663.83.2.195

Niess, M. (2005). Preparing teachers to teach science and mathematics with technology: Developing a technology pedagogical content knowledge. Teaching and Teacher Education, 21(5), 509-523.

Niess, M. (2006). Guest Editorial: Preparing teachers to teach mathematics with technology. Contemporary Issues in Technology and Teacher Education, 6(2), 195-203.

Prensky, M. (2012). From Digital Natives to Digital Wisdom. From Digital Natives to Digital Wisdom: Hopeful Essays for 21st Century Education, 1-9.

Roussinos, D., \& Jimoviannis, A. (2019). Examining primary education teachers' perceptions of TPACK and the related educational context factors. Journal of Research on Technology in Education, 51(4), 377397.

Sang, G., Valcke, M., Van Braak, J., \& Tondeur, J. (2010). Student teachers' thinking processes and ICT integration: Predictors of prospective teaching behaviours with educational technology. Computers \& Education, 51(4), 103-112.

Saralar, İ., \& Ainsworth, S. (2017). An exploration of middle school mathematics teachers' beliefs and goals regarding GeoGebra: Four cases from the Turkish Republic. Paper presented at the ECER 2017: Reforming Education and the Imperative of Constant Change: Ambivalent roles of policy and educational research. Denmark, Copenhagen, University College Copenhagen: European Educational Research Association.

Saralar, İ., Isiksal, M., \& Akyuz, D. (2016). A study on a pre-service mathematics teacher's technological pedagogical content knowledge regarding different views of 3 -d figures in geometry. Paper presented at the ECER 2016: Leading Education: The Distinct Contributions of Educational Research and Researchers. Ireland, Dublin, University College Dublin: European Educational Research Association.

Schmidt, D. A., Baran, E., Thompson, A. D., Mishra, P., Koehler, M. J., \& Shin, T. S. (2009). Technological Pedagogical Content Knowledge (TPACK). Journal of Research on Technology in Education, 42(2), 123-149.

Shin, T., Koehler, M., Mishra, P., Schmidt, D., Baran, E., \& Thompson, A. (2009). Changing Technological Pedagogical Content Knowledge (TPACK) through Course Experiences (pp. 4152-4159). Presented 
at the Society for Information Technology \& Teacher Education International Conference, Association for the Advancement of Computing in Education (AACE). Retrieved from https://www.learntechlib.org/primary/p/31309/

Shulman, L. (1986). Those who understand: Knowledge growth in teaching. Educational Researcher, 15(2), 4-14.

Sullivan, S. (2018). Bringing theory and practice together to develop a mathematics-specific observation tool for use with mathematics trainee teachers. In British Educational Research Association: British Society for Learning into Teaching Mathematics Spring 2018 Conference (pp. 12-13). Nottingham, The University of Nottingham, UK: BERA.

Showbie: The Paperless Classroom App for Teachers. (2019). Retrieved 28 March 2019, from Showbie website: https://www.showbie.com/

Starkey, L. (2010). Teachers' pedagogical reasoning and action in the digital age. Teachers and Teaching: Theory and Practice, 16(2), 233-244).

The University of Nottingham. (2018, May 25). GDPR. Retrieved 10 March 2019, from https://www.nottingham.ac.uk/legalservices/podbriefings/gdpr/gdpr.aspx

Vanderlinde, R., \& Braak, J. van. (2011). A New ICT Curriculum for Primary Education in Flanders: Defining and Predicting Teachers' Perceptions of Innovation Attributes. Journal of Educational Technology \& Society, 14(2), 124-135.

Wright, S. P., Horn, S. P., \& Sanders, W. L. (1997). Teacher and classroom context effects on student achievement: Implications for teacher evaluation. Journal of Personnel Evaluation in Education, 11(1), 57-67.

Yin, R. K. (2003). Case Study Research: Design and Methods. 3rd ed. Thousand Oaks, CA: Sage. 